\title{
Meanders of an Atypical Research Work on Helicobacter pylori in the Democratic Republic of Congo: Influence of HIV and other Factors and Study of some Interesting Cases
}

\author{
J. Ndelo-di-Phanzu ${ }^{1 *}$, Mputu Malolo ${ }^{1}$, P. Ndelo Matondo ${ }^{1}$, Y. Nuapia ${ }^{1}$, Tsomba Hondo Bin Salum ${ }^{2}$ and S. Mbendi Nsukini ${ }^{3}$ \\ ${ }^{1}$ Laboratory of Toxicology, University of Kinshasa, Kinshasa, Democratic Republic of the Congo \\ ${ }^{2}$ Forensic Medicine Institute, General Hospital of Kinshasa, Kinshasa, Democratic Republic of the Congo \\ ${ }^{3}$ Department of Gastroenterology, School of Medicine, University of Kinshasa, Kinshasa, Democratic Republic of the Congo
}

*Corresponding author: Phanzu JND, Laboratory of Toxicology, University of Kinshasa, Kinshasa, Democratic Republic of the Congo, Tel: + 243810265700 ; E-mail: jos_ndelo@yahoo.fr

Received date: December 29, 2017; Accepted date: January 08, 2018; Published date: January 12, 2018

Copyright: () 2018 Phanzu JND, et al. This is an open-access article distributed under the terms of the Creative Commons Attribution License, which permits unrestricted use, distribution, and reproduction in any medium, provided the original author and source are credited.

\begin{abstract}
During the $3^{\text {rd }}$ Euro case reports in Valencia, Spain, a strange medical case taking place in the DRC has been presented. Indeed, while the Congolese population is, until now, convinced of the existence of massive criminal poisonings, throughout the national area, originating from the East region of the country, we incredibly observed and demonstrated that actually, the phenomenon is a silent, surprising and unexpected Helicobacter pylori epidemic with numerous extra-digestive pathologies. The present subject will deal with picturesque meanders by which our research work passed, lengthening it to more than twenty years before getting appropriate results. The presentation will start by a brief summary of the DRC Helicobacter pylori phenomenon described in Valencia and hypothesis raised for better knowledge of Helicobacter pylori infection, at the international level. In a second time, it will focus on the influence and consequences of some followed factors in our study: HIV infection, political situation in DRC, lack of equipment and financial means, population ignorance, traditional practitioners' cupidity, deficiency of south-North collaboration, and so on. Afterwards, two interesting incredible extra-digestive DRC Helicobacter pylori cases observed in our study will be discussed. Finally a brief conclusion will present some useful propositions drawn from the experience of this DRC Helicobacter pylori research work.
\end{abstract}

Keywords: Helicobacter pylori; Extra-gastric pathologies; $\mathrm{RD}$ Congo; Euro case reports; Karoo phenomenon; HIV influence

\section{Introduction}

In 1990, in the Democratic Republic of the Congo, Mobutu's regime was at its end and political, social, cultural country environment was very bad. The country was under general international embargo for political reasons. All partners of education of Congolese universities left the country and all of our laboratories lacked of equipment. Medical situation was also bad because of the HIV general infection which was at its top in the country.

It's in that period of time that we started at the Laboratory of Toxicology of the University of Kinshasa a cross-sectional study of a strange disease present in DR Congo since a few decades, characterized by huge digestive and extra-digestive pathologies, considered by Congolese population as a result of massive criminal poisonings throughout the country. Internal heat, suffocation, mental confusion, heart pain, intense tiredness and loose of weight were the principal symptoms of that phenomenon.

During the $3^{\text {rd }}$ Euro case reports in Valencia Spain, in 2016, the strange medical case taking place in DR Congo has been presented. Indeed, contrary to the conviction of the Congolese population about the existence of massive criminal poisonings, throughout the country, we incredibly observed and demonstrated, in 2010, a surprising and unexpected Helicobacter pylori epidemic with numerous extradigestive pathologies.
This paper deals with the presentation made during the $5^{\text {th }}$ Clinical and Medical Euro case reports held in Paris, France in 2017 September 07 to 08 , explaining picturesque meanders by which our research work passed, before getting appropriate results. According to the presentation, it will focus first on a brief summary of Helicobacter pylori phenomenon described in Valencia and hypothesis raised for the better knowledge of Helicobacter pylori infection, at the international level. Afterwards the influence and consequences of some delaying factors will be presented. Finally, two extra-digestive Helicobacter pylori cases observed in our study will be discussed.

\section{Methods}

\section{Study design and sample}

This paper is based on a cross-sectional study conducted on Karoo patients received at the Laboratory of Toxicology of the University of Kinshasa from January 2005 to June 2016. The study protocol has been submitted to the Internal Review Board of the Faculty of Pharmaceutical Sciences of the University of Kinshasa and it has been conducted according to the principles of the Helsinki Declaration (Ethical Principles of Medical Research Involving Human Subjects) as amended in 2013.

\section{Variables of study}

Questionnaire for data collection included three parts. The first part concerned socio-demographic variables: age, sex, educational level and 
Citation: Phanzu JND, Malolo M, Matondo PN, Nuapia Y, Salum THB, et al. (2018) Meanders of an Atypical Research Work on Helicobacter pylori in the Democratic Republic of Congo: Influence of HIV and other Factors and Study of some Interesting Cases. J Pharmacogenomics Pharmacoproteom 9: 176. doi:10.4172/2153-0645.1000176

Page 2 of 8

marital status. The second part described "Karoo phenomenon": symptoms, origin, circumstances of poisoning, traditional diagnostic and treatment, opinions of Karoo patients on this phenomenon. The third part addressed the relationship between "Karoo phenomenon" and Helicobacter pylori. Scientific parameters were: saliva $\mathrm{pH}$, toxicological screening (Thin layer chromatography, and UV spectrophotometer), Blood sedimentation rate, Alanine Aminotransferase test (ALAT), Aspartate Aminotransferase test (ASAT), Urea, Creatinine, Helicobacter pylori (Chromatographic serological method), Hemoglobin, and Glucose.

\section{Case reports}

Two cases were reported: a patient's case, and a post-mortem case. The two cases have been selected for their especial feature. Patient's case concerned a woman of 36 year's old, single, employed in a private communication enterprise. The post-mortem case concerned a 40 years old man, married, self-employed. They were both positive to Helicobacter pylori with extra-digestive evident signs, displayed in photos in attachment.

\section{Results}

\section{Population of study}

Table 1 shows that the population of study included 402 patients received at the Laboratory of Toxicology of the University of Kinshasa from January 2005 to June 2016, 277 males and 125 females. Patients from 20 to 50 years old were more represented in the population of study but there were also 21 patients beyond 50 years old and 4 children less than 5 years old. Unmarried patients were $181(45 \%)$ while the currently married patients were 193 (48\%). The number of patients received was in ascendant progression: 40 (9.9\%) from 2005 to 2009, 56 (13.6\%) from 2010 to 2013 and 306 (76.1\%) from 2013 to 2016.

\begin{tabular}{|c|c|c|}
\hline Variables & Patients & Percentage \\
\hline \multicolumn{3}{|l|}{ Sex } \\
\hline Male & 277 & 68.9 \\
\hline Female & 125 & 31.1 \\
\hline Total & 402 & \\
\hline \multicolumn{3}{|l|}{ Age (years) } \\
\hline $0-5$ & 4 & 0.9 \\
\hline $6-20$ & 21 & 5.2 \\
\hline $21-50$ & 349 & 86.9 \\
\hline \multirow[t]{2}{*}{$<50$} & 28 & 6.9 \\
\hline & 402 & \\
\hline \multicolumn{3}{|c|}{ Educational level } \\
\hline No education & 55 & 13.6 \\
\hline Primary & 97 & 24.1 \\
\hline High & 145 & 36 \\
\hline Higher & 105 & 26.1 \\
\hline
\end{tabular}

\begin{tabular}{|c|c|c|}
\hline \multicolumn{3}{|l|}{ Current marital status } \\
\hline Unmarried & 181 & 45 \\
\hline Married & 193 & 48 \\
\hline Formerly married & 28 & 6.9 \\
\hline \multicolumn{3}{|l|}{ Residence } \\
\hline East of the country & 185 & 46 \\
\hline Kinshasa & 143 & 36 \\
\hline $\begin{array}{l}\text { Other provinces of west } \\
\text { of the country }\end{array}$ & 74 & 18 \\
\hline \multicolumn{3}{|c|}{ Patients progression from 2005 to 2016} \\
\hline $2005-2009$ & 40 & 9.9 \\
\hline $2010-2012$ & 56 & 13.9 \\
\hline $2013-2016$ & 306 & 76.1 \\
\hline
\end{tabular}

Table 1: Socio-demographic variables $(n=402)$.

\section{Characteristics of Karoo poisoning}

Symptoms: Symptoms were diversified. They were digestive but most extra-digestive as well, divided in general and nervous symptoms (Table 2).

\begin{tabular}{|c|c|c|}
\hline Digestive Symptoms & General Symptoms & Nervous Symptoms \\
\hline $\begin{array}{l}\text { Heat in the stomach and } \\
\text { thorax }\end{array}$ & Weight loss & Vertigo \\
\hline Intense abdominal pain & High internal heat & Early aging \\
\hline Throat dryness & High transpiration & Frequent forgetting \\
\hline Tongue and mouth burn & $\begin{array}{l}\text { General and sexual } \\
\text { tiredness }\end{array}$ & Mental confusion \\
\hline Hyper-salivation & Suffocation & Consciousness loss \\
\hline Nausea without vomiting & Anemia & Memory disorders \\
\hline Regurgitation & Skin allergy & Hallucinations \\
\hline Constipation & Skin blackening & $\begin{array}{l}\text { Intermittent hands } \\
\text { shaking }\end{array}$ \\
\hline Loss of appetite & High blood pressure & Paralysis \\
\hline $\begin{array}{l}\text { Bitter taste of food and } \\
\text { beverages }\end{array}$ & $\begin{array}{l}\text { Sensation of something } \\
\text { moving under the skin }\end{array}$ & $\begin{array}{l}\text { Electroencephalogramm } \\
\text { disturbance }\end{array}$ \\
\hline Alkaline Saliva & High blood sugar & $\begin{array}{l}\text { Sensation of something } \\
\text { moving into the head }\end{array}$ \\
\hline $\begin{array}{l}\text { Increase of Saliva } \\
\text { viscosity }\end{array}$ & $\begin{array}{l}\text { Increase of blood } \\
\text { viscosity }\end{array}$ & Blurred vision \\
\hline Stomach distending & Pricking sensation & Frequent drowsiness \\
\hline Sanguinolent spit & Heart palpitations & \\
\hline Anorexia & $\begin{array}{l}\text { Hormonal disorders on } \\
\text { women }\end{array}$ & \\
\hline Diarrhea & Hard breathing & \\
\hline
\end{tabular}


Citation: Phanzu JND, Malolo M, Matondo PN, Nuapia Y, Salum THB, et al. (2018) Meanders of an Atypical Research Work on Helicobacter pylori in the Democratic Republic of Congo: Influence of HIV and other Factors and Study of some Interesting Cases. J Pharmacogenomics Pharmacoproteom 9: 176. doi:10.4172/2153-0645.1000176

Page 3 of 8

\begin{tabular}{|l|l|l|}
\hline Stomach buzz & Breathlessness & \\
\hline $\begin{array}{l}\text { Sensation of stomach } \\
\text { fullness }\end{array}$ & $\begin{array}{l}\text { Increase of blood } \\
\text { alkalinity }\end{array}$ & \\
\hline
\end{tabular}

Table 2: Symptoms collected in DR Congo.

\section{Opinions of patients on Karoo phenomenon}

Table 3 presents opinions of patients on Karoo phenomenon. Most patients thought that Karoo symptoms could last months $(275,68.4 \%)$ or years $(58,14.4 \%)$. The eastern of the country was identified unanimously as the principal site of Karoo poisoning (402, 100\%). Four principal symptoms were identified: internal heat (282, 70.1\%), bitterness of food and beverages (257, 69.9\%), intense tiredness (275, $68.4 \%)$ and inexplicable loss of weight $(269,66.9 \%)$. In case of Karoo poisoning, preference was to visit traditional practitioners instead of going to the hospital. Three traditional diagnostic tests were pointed out, all conducted on patients' saliva. Traditional treatment was centered on the honey, sometimes mixed to lemon and garlic juice (402, 100\%). The recourse to the Laboratory of Toxicology was directed by two main reasons: traditional treatment failure (388, $96.5 \%)$ and the need of scientific diagnosis $(346,86 \%)$.

\begin{tabular}{|l|l|l|}
\hline Variables & Patients & Percentage \\
\hline Duration of "Karoo symptoms" & 120 & 29.8 \\
\hline Days & 143 & 35.5 \\
\hline Weeks & 275 & 68.4 \\
\hline Months & 58 & 14.4 \\
\hline Years & 58 & \\
\hline
\end{tabular}

Principal poisoning site

\begin{tabular}{|l|l|l|}
\hline East of the country & 402 & 100 \\
\hline Kinshasa & 46 & 11.4 \\
\hline Other provinces of west of the country & 20 & 4.9 \\
\hline
\end{tabular}

Principal sign of Karoo poisoning

\begin{tabular}{|l|l|l|}
\hline Bitterness of food or beverages & 257 & 69.9 \\
\hline Nausea without vomiting & 198 & 49.2 \\
\hline Tiredness & 275 & 68.4 \\
\hline Internal heat & 282 & 70.1 \\
\hline Inexplicable loss of weight & 269 & 66.9 \\
\hline
\end{tabular}

Reasons for going to traditional practitioners instead of to the hospital

Traditional practitioners are Karoo specialists

\begin{tabular}{|l|l|l|}
\hline They have a rapid and efficient test & 402 & 100 \\
\hline They have efficient treatments & 402 & 100 \\
\hline At the hospital there is no test for poison & 196 & 48.7 \\
\hline At the hospital Karoo poisoning is denied & 368 & 91.5 \\
\hline There is no modern efficient treatment & 402 & 100 \\
\hline
\end{tabular}

\begin{tabular}{|c|c|c|}
\hline Modern medicines get Karoo poisoning worse & 402 & 100 \\
\hline & 402 & 100 \\
\hline \multicolumn{3}{|l|}{ Principal traditional test made on patients' saliva } \\
\hline Spit in a glass of water & 385 & 95.7 \\
\hline Spit on a tongue of a yellow paper & 242 & 60.1 \\
\hline Spit in a tender leaf of a plant & 80 & 19.9 \\
\hline \multicolumn{3}{|l|}{ Traditional treatment } \\
\hline Strong medicinal laxatives plants extracts & 195 & 48.5 \\
\hline Mixture of lemon, garlic and honey & 402 & 100 \\
\hline Other unknown mixtures & 72 & 17.9 \\
\hline Honey & 402 & 100 \\
\hline \multicolumn{3}{|c|}{ Reasons for coming to Laboratory of Toxicology } \\
\hline Traditional treatment failure & 388 & 96.5 \\
\hline Need of a scientific diagnosis & 346 & 86 \\
\hline Danger of medicinal plants & 88 & 21.8 \\
\hline Need of scientific control & 261 & 64.9 \\
\hline
\end{tabular}

Table 3: Opinions of patients on Karoo phenomenon $(n=402)$.

\section{Biological parameters}

Table 4 shows biological parameters checked. Toxicological screening and Saliva alkalinity determination were performed in all the patients from 2005 to 2016. The others biomarkers (H. pylori, sedimentation rate, hemoglobin, ASAT, ALAT, creatinine and urea) were recorded only since 2013 , in 306 patients. H. pylori and saliva alkalinity were positive to all patients examined. Sedimentation rate was high $(<10 \mathrm{~mm} / \mathrm{h})$ in most patients $(270,88.2 \%)$. The toxicological screening was positive in $46(11.4 \%)$ patients; the toxic in cause in every case was paracetamol. ALAT and ASAT were normal for most patients $(260,84.9 \%)$. The eradication of $H$. pylori was obtained in 280 patients (91.5\%). Symptoms were also cleared in 280 patients (91.5\%). Resistance rate to treatment was then $8.5 \%$. Iron deficiency anemia was present in 80 patients (26.1\%).

\begin{tabular}{|c|c|c|}
\hline Parameters & Patients & Percentage \\
\hline \multicolumn{3}{|c|}{ Toxicological screening $(n=402)$} \\
\hline Positive & 46 (paracetamol) & 11.4 \\
\hline Negative & 356 & 88.5 \\
\hline \multicolumn{3}{|c|}{ Saliva alkalinity $(n=402)$} \\
\hline Yes & 376 & 93.5 \\
\hline No & 26 & 6.4 \\
\hline \multicolumn{3}{|c|}{ H. pylori $(n=362)$} \\
\hline Positive & 362 & 100 \\
\hline Negative & 0 & \\
\hline
\end{tabular}


Citation: Phanzu JND, Malolo M, Matondo PN, Nuapia Y, Salum THB, et al. (2018) Meanders of an Atypical Research Work on Helicobacter pylori in the Democratic Republic of Congo: Influence of HIV and other Factors and Study of some Interesting Cases. J Pharmacogenomics Pharmacoproteom 9: 176. doi:10.4172/2153-0645.1000176

Page 4 of 8

\begin{tabular}{|c|c|c|}
\hline Negative after treatment & 280 & 91.5 \\
\hline Still positive after treatment & 26 & 8.4 \\
\hline Clearance of the symptoms after treatment & 280 & 91.5 \\
\hline \multicolumn{3}{|l|}{ Hemoglobin $(n=306)$} \\
\hline Normal & 226 & 73.8 \\
\hline Abnormal (under the norm) & 80 & 26.1 \\
\hline \multicolumn{3}{|l|}{ Aspartate amino transferase ASAT $(n=306)$} \\
\hline Normal & 260 & 84.9 \\
\hline Abnormal (up to the norm) & 46 & 15 \\
\hline \multicolumn{3}{|l|}{ Alanine amino transferase ALAT $(n=306)$} \\
\hline Normal & 260 & 84.9 \\
\hline Abnormal (up to the norm) & 46 & 15 \\
\hline Creatinin ( $n=306$ ) & & \\
\hline
\end{tabular}

\begin{tabular}{|c|c|c|}
\hline Normal & 302 & 98.6 \\
\hline Abnormal (up to the norm) & 4 & 1.3 \\
\hline \multicolumn{3}{|l|}{ Urea ( $n=306)$} \\
\hline Normal & 302 & 98.6 \\
\hline Abnormal (up to the norm) & 4 & 1.3 \\
\hline \multicolumn{3}{|c|}{ Blood sedimentation rate $(n=306)$} \\
\hline Normal & 36 & 8.9 \\
\hline Abnormal (up to the norm) & 270 & 88.2 \\
\hline
\end{tabular}

Table 4: Results of biological parameter.

\section{Case reports parameters}

\section{Patient's case parameters}

\begin{tabular}{|l|l|l|}
\hline \multicolumn{2}{|l|}{ BIOLOGICAL PARAMETERS } & SYMPTOMS \\
\hline Helicobacter pylori & Positive & Feet swelling \\
\hline Blood sedimentation rate & $85 \mathrm{~mm} / \mathrm{h}(<10 \mathrm{~mm} / \mathrm{h})$ & Internal heat in stomach and thorax \\
\hline Alanine aminotransferase & $24 \mathrm{U} / \mathrm{L}(0-41 \mathrm{U} / \mathrm{L})$ & Dizziness \\
\hline Aspartate aminotransferase & $28 \mathrm{U} / \mathrm{L}(0-31 \mathrm{U} / \mathrm{L})$ & Headache \\
\hline Urea & $30 \mathrm{mg} / \mathrm{dl}(15-45 \mathrm{mg} / \mathrm{dl})$ & Intense tiredness \\
\hline Creatinine & $1,2 \mathrm{mg} / \mathrm{dl}(0,5-1,5 \mathrm{mg} / \mathrm{dl})$ & Cough \\
\hline
\end{tabular}

Table 5: Patients' case parameters.

\section{Post-mortem case parameters}

\begin{tabular}{|l|l|l|}
\hline \multicolumn{2}{|l|}{ BIOLOGICAL PARAMETERS } & AUTOPSY FINDINGS \\
\hline Helicobacter pylori & $\begin{array}{l}\text { Positiv } \\
\text { e }\end{array}$ & Gut distending \\
\hline Blood sedimentation rate & - & Stomach distending \\
\hline Alanine aminotransferase & - & Brain congestion \\
\hline $\begin{array}{l}\text { Aspartate } \\
\text { aminotransferase }\end{array}$ & - & Lungs congestion \\
\hline Urea & - & Cyanosis of lips, fingers and toes \\
\hline Creatinine & - & Tongue biting \\
\hline- & - & $\begin{array}{l}\text { Pallor of hands palms and of sole of the } \\
\text { feet }\end{array}$ \\
\hline- & - & Cardiomegaly \\
\hline- & - & Eyes red coloration \\
\hline- & - & Nose bleeding \\
\hline- & - & Gastric bleeding \\
\hline
\end{tabular}

Table 6: Post-mortem case parameters.

\section{Discussion}

\section{Summary of main findings}

The strange phenomenon characterized by huge extra-digestive pathologies, current in Democratic Republic of Congo, considered as massive criminal poisoning, appeared actually caused by Helicobacter pylori. (ii) Its characteristics and symptoms have been collected (Table 2). (iii) Helicobacter pylori outbreak in DRC needed environment activator factors. (v) Patients' saliva was alkalized by gas ammonia flying up from stomach to mouth. (vi) Gas ammonia and carbon dioxide are responsible of huge patients' extra-digestive pathologies. Carbone dioxide combines causticity and redoubtable fatal asphyxia power, as demonstrated in the post-mortem case.

\section{Helicobacter pylori infection}

Helicobacter pylori, is well known worldwide. It largely colonizes humans since immemorial time, in both developing and developed countries [1-24]. It's widely involved in gastritis, asymptomatic for most infected individuals. A small proportion of infected individuals develop more dangerous gastritis involving peptic ulceration and gastric malignancy [22,25-33]. Helicobacter pylori is responsible for tremendous morbidity and mortality throughout the world $[6,7,12,14-16]$. Normally originated in Africa, Helicobacter pylori has 
Citation: Phanzu JND, Malolo M, Matondo PN, Nuapia Y, Salum THB, et al. (2018) Meanders of an Atypical Research Work on Helicobacter pylori in the Democratic Republic of Congo: Influence of HIV and other Factors and Study of some Interesting Cases. J Pharmacogenomics Pharmacoproteom 9: 176. doi:10.4172/2153-0645.1000176

Page 5 of 8

been carried with human populations around the world after their departure from Africa [26,29]. Helicobacter pylori infected persons increase risk of developing gastric cancer. Many factors and cofactors influence gastric cancer development [8,10,32-34]. Helicobacter pylori virulence is under the control of Helicobacter pylori gene factors $[25,27,30,31]$. There is actually an important change in the relationships between helicobacter pylori and humans, caused by modern life change in gut micro-ecology [19,29]. In Africa, Helicobacter pylori infection displays a specificity called "African enigma" related to the fact that, in spite of a high Helicobacter pylori contamination in Africa, often from early childhood, gastric cancer prevalence is inexplicably low $[6,17,21]$.

\section{DRC Helicobacter pylori phenomenon}

Congolese population is, until now, convinced that the phenomenon current in DR Congo is a consequence of massive criminal poisonings. Yet, our study established, in 2010, an unexpected interesting link with Helicobacter pylori. According to Table 4, the 362 patients received at the Laboratory of Toxicology of the University of Kinshasa for poisoning suspicion, were all positive to Helicobacter pylori. They were all characterized by huge extra-digestive pathologies (Table 2). Main pathologies identified were: internal heat $(282,70.1 \%)$, bitterness of food and beverages $(257,69.9 \%)$, intense tiredness $(275,68.4 \%)$ and inexplicable loss of weight $(269,66.9 \%)$. Following other hypothesis was raised in our study: (i) numerous extra-digestive pathologies observed, indicated a free and massive passage of ammonia and carbon dioxide to the blood. (ii) Ammonia and carbon dioxide released in stomach by the reaction urea-urease, in gaseous state, should be eliminated in stools. (iii) In case of constipation however, ammonia and carbon dioxide, still in gaseous state, could go up along the esophagus to the mouth and lungs and from there to the blood stream. (iv) A double intoxication then occurs, justifying numerous extradigestive pathologies described in Table 2. (v) This statement is in perfect harmony with recent literature which reports more and more extra-digestive pathologies linked to Helicobacter pylori [23,28,35-41].

\section{Proposed improvements on Helicobacter pylori infection}

Under the light of our study, some following improvements would be proposed for best Helicobacter pylori infection understanding: (i). Helicobacter pylori infection should be named Helicobacter pylori toxic-infection to take count of the intoxication component present in many cases of Helicobacter pylori infection as frequently stated in recent literature. (ii). Helicobacter pylori extra-digestive symptoms should be definitely recognized as part of Helicobacter pylori infection. (iii) Passage of Helicobacter pylori toxins in blood via lungs way should be acknowledged. (iv). Helicobacter pylori treatment should be reevaluated to take in count the intoxication component. Our study suggested that toxicological eliminating treatment should always be combined to Helicobacter pylori medical eradication treatment. (v). the development of a rapid Helicobacter pylori diagnosis method based on ammonia identification in saliva and in stools could be useful.

\section{An atypical wandering research work}

Our research work took a long time before getting suitable results because, mainly, of unfavorable political, social, cultural and scientific environment of the end of Mobutu's regime in DR Congo and the war it generated. The international political embargo imposed to DR Congo since 1990, provoked lack of equipment, lack of financial means for research and lack of useful South-North collaboration. Secondly, Karoo poison was not only unknown but invisible physically as well.

Thirdly, rumors, traditional believe of Congolese population and cupidity of traditional practitioners played an important impairment role. For example, as reported in Table 3, modern medicines were reputed to be inefficient against Karoo poison. The use of modern medicines, especially by perfusion, was even thought to rapidly lead to death. The consequence was that in many villages, most in the eastern region of the country, people avoided going to the hospital, for any disease. As it could be guessed, HIV/AIDS, tuberculosis and malaria took big advantage of this situation.

Some symptoms reported in Table 2, like intense tiredness, anorexia and most significant loss of weight was commune to Karoo phenomenon and to HIV. The confusion with HIV was a major complication factor in our study.

Opinion of some Congolese medical staff, denying findings concerning the role of Helicobacter pylori in Congolese Karoo phenomenon was also an important source of wandering.

\section{Case Reports}

As displayed in Figures 1-6, patient's case main pathology was feet swelling. Helicobacter pylori was positive, blood sedimentation rate high $(85 \mathrm{~mm} / \mathrm{h})$, alanine aminotransferase, aspartate aminotransferase, urea and creatinine, were in normal range (Table 5). No hypertension and diabetes diseases. Swelling was accompanied by internal heat in stomach and thorax, dizziness, headache, reflex cough, and intense tiredness (Table 5). Feet swelling was attributed to Helicobacter pylori $\mathrm{CO}_{2}$ toxin, after its passage to the blood via the lungs way, as stated in this study. Activated charcoal guaranteed feet deflating within ten days (Table 5).

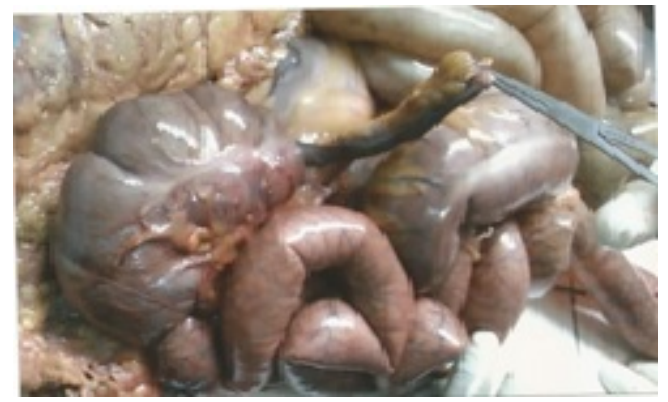

Figure 1: Gut distending photo forensic medicine institute/ Kinshasa. 
Citation: Phanzu JND, Malolo M, Matondo PN, Nuapia Y, Salum THB, et al. (2018) Meanders of an Atypical Research Work on Helicobacter pylori in the Democratic Republic of Congo: Influence of HIV and other Factors and Study of some Interesting Cases. J Pharmacogenomics Pharmacoproteom 9: 176. doi:10.4172/2153-0645.1000176

Page 6 of 8

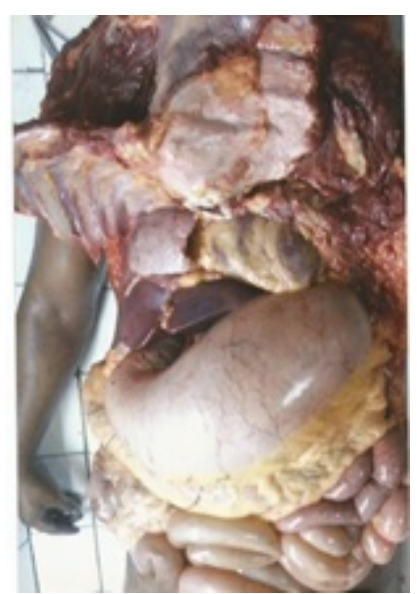

Figure 2: Stomach distending photo forensic medicine institute/ Kinshasa.

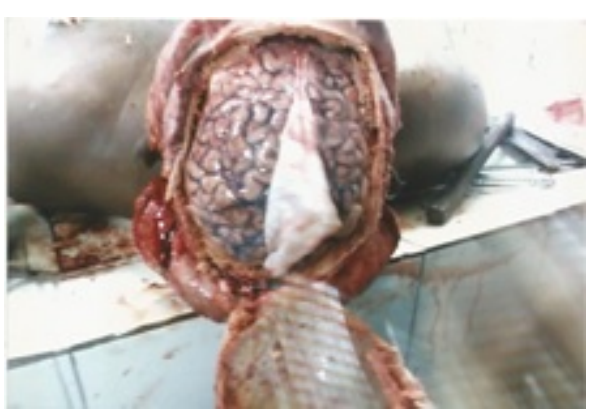

Figure 3: Brain Congestion photo forensic medicine institute/ Kinshasa.

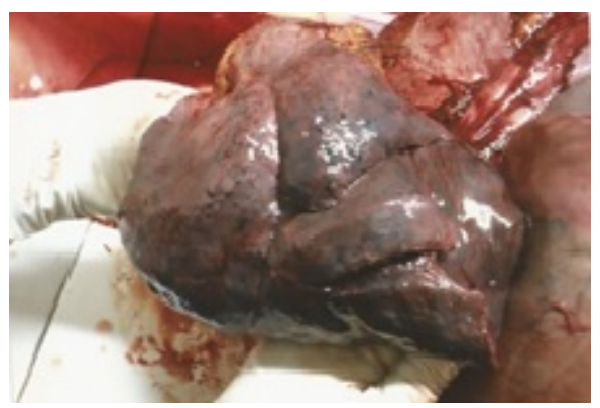

Figure 4: Right Lung Congestion photo forensic medicine institute/ Kinshasa.
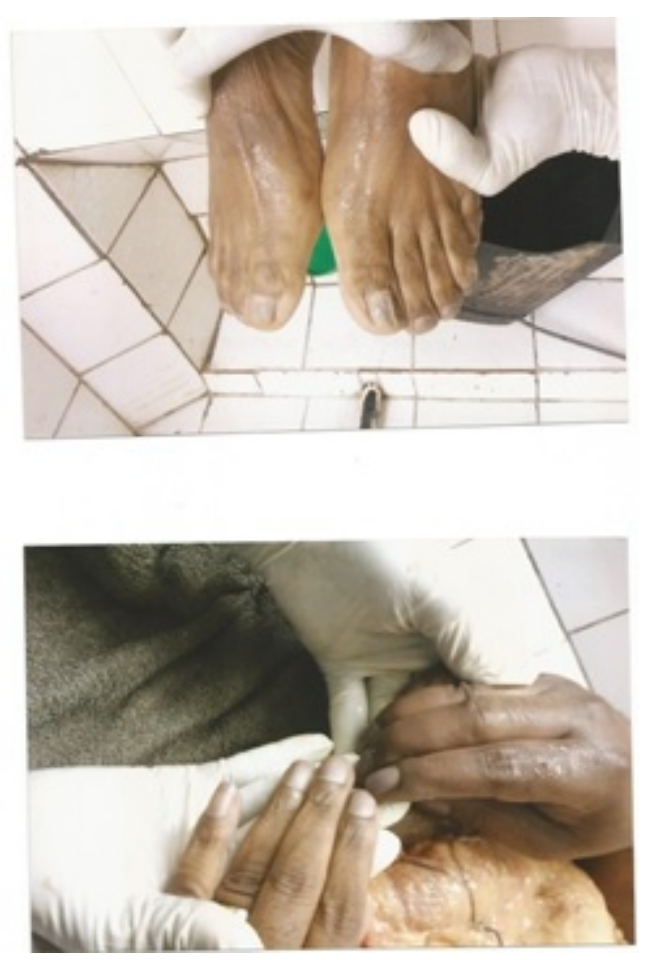

Figure 5: Fingers and toes cyanosis photo forensic medicine institute/Kinshasa.

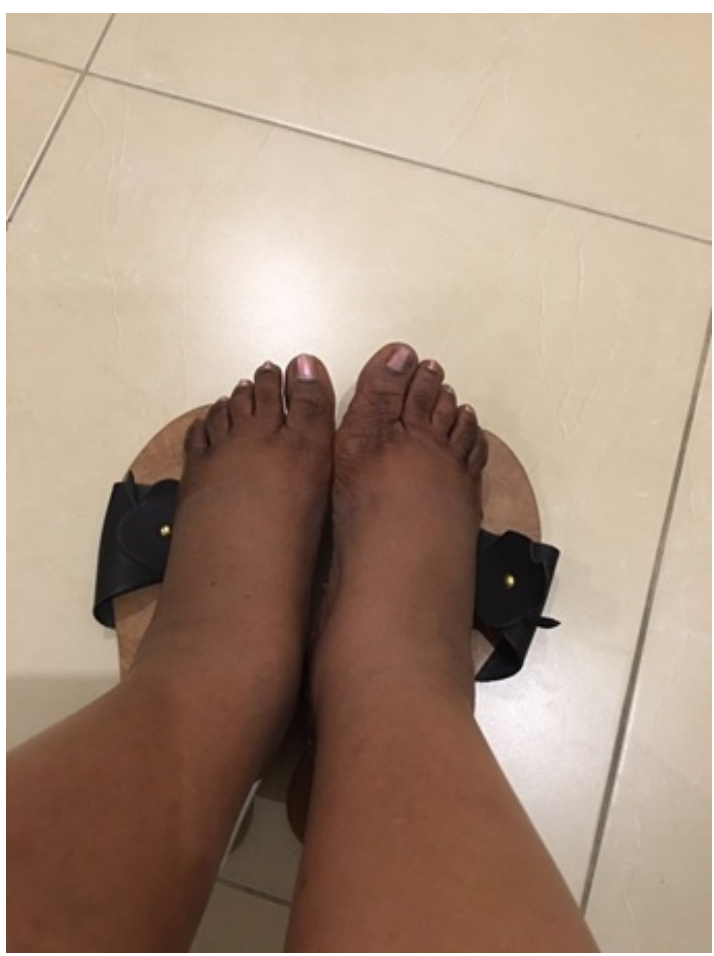

Figure 6: Feet swelling photo Shafali/Kinshasa. 
Citation: Phanzu JND, Malolo M, Matondo PN, Nuapia Y, Salum THB, et al. (2018) Meanders of an Atypical Research Work on Helicobacter pylori in the Democratic Republic of Congo: Influence of HIV and other Factors and Study of some Interesting Cases. J Pharmacogenomics Pharmacoproteom 9: 176. doi:10.4172/2153-0645.1000176

Page 7 of 8

The post-mortem case was received, from Forensic Medicine Institute of General Hospital of Kinshasa for toxicological analysis, after a suspect death. Death occurred suddenly, at home, during the night, after the return from a friend's party. Immediately after death, stomach inflated extremely at an incredible speed. Autopsy findings were unexpected and amazing. Autopsy statement revealed full of abnormalities, notably: Gut distending, Stomach distending, Brain congestion, Lungs congestion, Cyanosis of lips, fingers and toes, Tongue biting, Pallor of Hands palms and pallor of sole of the feet, Cardiomegaly, Eyes red coloration, Nose bleeding, Gastric bleeding (Table 6). All those abnormalities were identified as sign of double intoxication by gas ammonia and carbon dioxide. Death occurred bluntly after brutal carbon dioxide asphyxia. Helicobacter pylori was incriminated, as the deceased was a known Helicobacter pylori chronic gastritis patient. Those two cases, selected among many others, were significant testimony of the findings of this study.

\section{Conclusion}

Our research work was very time consuming because it did face many obstacles. In spite of all problems faced, we did never give up. Results got after a so long period of time beyond 20 years of wandering, seem impressive. It's necessary not to forget that in spite of all disturbances in Sub-Saharan African countries, many scientific researchers are there, trying painfully to contribute to the improvement of scientific world knowledge.

We think necessary to develop more scientific collaboration and networks between researchers from developing and developed countries, far beyond political considerations.

We encourage young research workers, to never give up. They have to know that in any research work, without a bit wandering mind, phenomenal results could never be achieved.

\section{References}

1. Cave DR (1996) Transmission and epidemiology of Helicobacter pylori. Am J Med 100: 12-17.

2. Pounder RE, Ng D (1995) The prevalence of Helicobacter pylori infection in different countries. Aliment Pharmacol Ther 9: 33-39.

3. Bardhan PK (1997) Epidemiological features of Helicobacter pylori infection in developing countries. Clin Infect Dis 25: 973-978.

4. Malaty HM, Graham DY (1994) Importance of childhood socioeconomic status on the current prevalence of Helicobacter pylori infection. Gut 35: 742-745.

5. Parente JM, da Silva BB, Palha-Dias MP, Zaterka S, Nishimura NF, et al. (2006) Helicobacter pylori infection in children of low and high socioeconomic status in northeastern Brazil. Am J Trop Med Hyg 75: 509-512.

6. Ankouane Andoulo F, Noah Noah D, Tagni-Sartre M, Ndjitoyap Ndam EC, Ngu Blackett K (2013) Epidemiology of infection Helicobacter pylori in Yaoundé: specificity of the African enigma. Pan Afr Med J 16: 115.

7. Nii Akushe Archampong T, Harry Asmah R, Kwame Wiredu E, Kwasi Gyasi R, Nyaako Nkrumah K, et al. (2015) Epidemiology of Helicobacter pylori infection in dyspeptic Ghanaian patients. Pan Afr Med J 20: 178.

8. Konturek PC, Konturek SJ, Brzozowki T (2013) Gastric cancer and Helicobacter pylori infection in DR Congo. Epidemiological aspects. Gastric cancer and Helicobacter pylori infection. Epidemiological Features in DR Congo 6.

9. Bomba di Masuangi E, Nkondi Nsenga J, Kabongo Mpolesha JM, Mbutiwi Ikwa NF, bara JR (2013) Dyspepsie et infection à Helicobacter pylori à Kinshasa (R.D. Congo). Médecine d'Afrique Noire 60: 519-526.
10. Kalengayi RM, Kabengele GK, Nkondi NJ, Muteba D, Tshiamala KKP (2011) Helicobacter pylori et cancer gastrique: expérience congolaise (RDC). Annales de Pathologie 5: 162-163.

11. Mendall MA, Goggin PM, Molineaux N, Levy J, Toosy T, et al. (1992) Childhood living conditions and Helicobacter pylori seropositivity in adult life. Lancet 339: 896-897.

12. Bomba E, Nkondi NJ, Ibara JR, Kabongo MJM, Mbutiwi INM (2014) "Étude de la relation entre le reflux gastro-oesophagien (RGO) et linfection à Helicobacter pylori à Kinshasa". J Afr d'HépatoGastroentérologie 8: 143-147.

13. Longo-Mbenza B, Nsenga JN, Mokondjimobe E, Gombet T, Assori IN, et al. (2012) "Helicobacter pylori infection is identified as a cardiovascular risk factor in Central Africans." Vasc Health Risk Manag 6: 455-461.

14. Nkondi Nsenga, J, Longo-Mbenza B, Kabongo Mpolesha JM, Mabwa L, Mbungu S, et al. (2007) "Séropositivité Pour Helicobacter Pylori, Gastrite À Helicobacter Pylori, Composantes de La Pression Artérielle邓: Réalité Du Risque Cardiovasculaire." J Afr d'Hépato-Gastroentérologie 1: 87-92.

15. Bomba E, Nkondi NJ, Kabongo MJ, Chirimwami R, Lebuaze MB, et al. (2013) "Cancer gastrique et infection à Helicobacter pylori en RD Congo. Aspects épidémiologiques". Ann Afr Med 6: 1506-1511.

16. Bomba E, Nkondi NJ, Kabongo MJM, Mbutiwi INF, Ibara JR (2013) "Dyspepsie et infection à Helicobacter pylori à Kinshasa (R.D. Congo)." Médecine d'Afrique Noire 60: 519-526.

17. Holcombe C (1992) Helicobacter pylori: the African enigma. Gut 33: 429-431.

18. Ally R, Segal I (1998) H. pylori infection-acquisition in children. In: Lastovica AJ, Newell DG, Lastovica EE, eds. Campylobacter, Helicobacter and Related Organisms. South Africa, Rustica Press: 565.

19. Blaser MJ (1998) Helicobacters are indigenous to the human stomach: duodenal ulceration is due to changes in gastric micro-ecology in the modern era. Gut 43: 721-727.

20. Cover TL, Blaser MJ (1999) Helicobacter pylori factors associated with disease. Gastroenterology 117: 257-260.

21. Segal I, Ally R, Mitchell H (2001) Helicobacter pylori-an African perspective. QJM 94: 561-565.

22. Lee YC, Chiang TH, Chou CK, Tu YK, Liao WC, et al. (2016) Association Between Helicobacter pylori Eradication and Gastric Cancer Incidence: A Systematic Review and Meta-analysis. Gastroenterology 150: 1113-1124.

23. Oshima T, Ozono R, Yano Y, Oishi Y, Teragawa H, et al. (2005) Association of Helicobacter pylori infection with systemic inflammation and endothelial dysfunction in healthy male subjects. J Am Coll Cardiol 45: $1219-1222$.

24. Cover T, Blaser MJ (2009) Helicobacter pylori in health and disease. Gastroenterology 136: 1863-1873.

25. Caroll IM, Ahmed N, Beesley SM, Khan AA, Ghousunnissa S, et al. (2003) Fine-structure Molecular Typing of Irish Helicobacter pylori isolates and Their Genetic Relatedness to Strains from four different continents. J Clin Micerobiol 41: 5755-5759.

26. Suto-Giron MJ, Ospina OE, Massay SE (2015) Elevated level of adaptation in Helicobacter pylori genomes from Japan; a link to higher incidences of gastric cancer? Evol Med Public Health 2015: 88-105

27. Miernyk K, Morris J, Bruden D, Mac Mahon B, Hurlburt D, et al. (2011) Characterization of Helicobacter pylori cagA and vacA Genotypes among Alaskans and their Correlation With Clinical Disease. J Clin Microbiol 49: 3114-3121.

28. Fong TL, Dooley CP, Dehesa M, Cohen H, Carmel R, et al. (1991) Helicobacter pylori infection in pernicious anemia: A prospective controlled study. Gastroenterology 100: 328-332.

29. Blaser MJ (1999) Hypothesis: The Changing Relationships of Helicobacter pylori and Humans: Implications for Health and Disease. J Infect Dis 179: 1523-1530.

30. Panyotopoulou EG, Sgouras DN, Papadakos KS, Petraki K, Breurec S, et al. (2010) CagA and VacA polymorphisms Are Associated with Distinct Pathological Features in Helicobacter pylori-infected Adults with Peptic Ulcer and non-Peptic Ulcer Disease. J Clin Microbiol 48: 2237-2239. 
Citation: Phanzu JND, Malolo M, Matondo PN, Nuapia Y, Salum THB, et al. (2018) Meanders of an Atypical Research Work on Helicobacter pylori in the Democratic Republic of Congo: Influence of HIV and other Factors and Study of some Interesting Cases. J Pharmacogenomics Pharmacoproteom 9: 176. doi:10.4172/2153-0645.1000176

Page 8 of 8

31. Lima M, Cruz Godoy AP. Clinical relevance of the cagA, vagA and iceA gentotypes of Helicobacter pylori in Brazilian clinical isolates. Immun Medical Microbio 36: 181-185.

32. Abadi ATB, Lee YY (2014) Helicobater pylori vacA as Marker for Gastric Cancer and Gastroduodenal Diseases: One but Not the Only Factor. J Clin Microbiol 52: 4451.

33. Oshima T, Ozono R, Yano Y, Oishi Y, Teragawa H, et al. (2005) Association of Helicobacter pylori infection with systemic inflammation and endothelial dysfunction in healthy male subjects. J Am Coll Cardiol 45: 1219-1222.

34. el-Omar EM, Penman ID, Ardill JE, Chittajallu RS, Howie C, et al. (1995) Helicobacter pylori infection and abnormalities of acid secretion in patients with duodenal ulcer disease. Gastroenterology 109: 681-691.

35. Di Simone N, Tersigni C, Cardaropoli S, Franceschi F, Di Nicuolo F, et al. (2017) Helicobacter pylori infection contributes to placental impairment in preeclampsia: basic and clinical evidences. Helicobacter 22.

36. Franceschi F, Gasbarrini A, Polyzos SA, Kountouras J (2015) Extragastric Diseases and Helicobacter pylori. Helicobacter 20: 40-46.
37. Hughes WS (2014) An Hypothesis: The Dramatic Decline in Heart Attacks in the United States is Temporally Related to the Decline in Duodenal Ulcer Disease and Helicobacter pylori Infection. Helicobacter 19: 239-241.

38. Hudak L, Jaraisy A, Haj S, Muhsen K (2017) An updated systematic review and meta-analysis on the association between Helicobacter pylori infection and iron deficiency anemia. Helicobacter 22.

39. Sun J, Rangan P, Bhat SS, Liu L (2016) A Meta-Analysis of the Association between Helicobacter pylori Infection and Risk of Coronary Heart Disease from Published Prospective Studies. Helicobacter 21: 11-23.

40. Lee SP, Lee SY, Kim JH, Sung IK, Park HS, et al. (2014) Correlation Between Helicobacter pylori Infection, IgE Hypersensitivity, and Allergic Disease in Korean Adults. Helicobacter 20: 49-55.

41. DE Bernard M, Josenhans C (2014) Pathogenesis of Helicobacter pylori Infection. Helicobacter 1: 11-18. 